\title{
Managing Conflict at Sea: The Case of Norway and Russia in the Svalbard Zone
}

\section{Andreas Østhagen ${ }^{\star}$}

\author{
Research Fellow, Fridtjof Nansen Institute, Oslo, Norway; PhD-candidate, University of \\ British Columbia, Vancouver, Canada
}

\begin{abstract}
:
In 1977, Norway established a maritime Fisheries Protection Zone (FPZ) around Svalbard, yet avoided claiming an outright Exclusive Economic Zone (EEZ). A dispute with Russia over the status of the Zone arose. In the late 1990s, Norwegian enforcement of fisheries regulations became stricter, as fish stocks were in decline. This led the Norwegian Coast Guard to attempt to arrest Russian fishing vessels on several occasions, resulting in reactions from Russian fishermen, as well as officials in Murmansk and Moscow. In 1998, 2001, 2005, and 2011 specifically, incidents had the potential to escalate beyond a fisheries issue. Today, an event in the maritime zone is of concern to both Norwegian and Russian authorities. Given the potential volatility of events in the FPZ, how do Norway and Russia manage to avoid escalation in the case of a crisis? Whereas previous scholarly work has explicitly focused on the legal status of Svalbard and its maritime zones, or looked at how Norway manages fisheries in cooperation with Russia, this article brings forth new knowledge by examining the specific incidents in the Zone and placing these in the wider context of conflict theory. Limited to the Norwegian perceptions of the dispute only, this article adds to our understanding of this specific issue of Arctic conflict management and governance. Based on several years of data collection through interviews, the argument put forth is that Norwegian and Russian cooperation is based on both mutual interests and the socializing effects of cooperative mechanisms, which in turn are key to avoid escalation in crisis-scenarios. In sum, we need to recognise how a combination of economic interests and the effects of socialisation have enabled Norway and Russia to keep conflict levels low, when incidents at sea have occurred.
\end{abstract}

Keywords: Russia; Norway; Svalbard Zone; coast guards; maritime cooperation; Arctic security; conflict management

Responsible Editor: Øyvind Ravna, UiT - The Arctic University of Norway, Tromsø, Norway.

Received: November 2017; Accepted: April 2018; Published: May 2018

`Correspondence to: ao@fni.no

(C)2018 A. Østhagen. This is an Open Access article distributed under the terms of the Creative Commons AttributionNonCommercial 4.0 International License (https://creativecommons.org/licenses/by-nc/4.0/), allowing third parties to share their work (copy, distribute, transmit) and to adapt it, under the condition that the authors are given credit, that the work is not used for commercial purposes, and that in the event of reuse or distribution, the terms of this license are made clear. 


\section{Introduction}

In 1977, Norway established a maritime Fisheries Protection Zone (FPZ) around the archipelago of Svalbard, north of the Norwegian mainland. Norway avoided claiming an outright Exclusive Economic Zone (EEZ) fearing it would be challenged by the global community due to stipulations (or lack thereof) concerning extended maritime zones in the Svalbard Treaty from 1920. ${ }^{1}$ Since then, Norway has managed economic activity in this maritime domain, principally fisheries. ${ }^{2}$ At the turn of the millennium, Norwegian fisheries enforcement became stricter, in tandem with declining fish stocks and fear of considerable IUU (illegal, unreported, and unregulated) fishing in the Barents Sea. The first example of this was the attempted arrest of the Russian fishing vessel Novokuybyshevsk in 1998. This led to reactions from Russian fishermen, as well as officials in both Murmansk and Moscow, which further peaked on later occasions, when the Norwegian Coast Guard attempted to arrest the Russian fishing vessels Chernigov in 2001, Elektron in 2005, and Sapphire II in 2011. The risk of events spiralling out of control in the FPZ remains a primary concern for both the Norwegian Coast Guard and the Norwegian Ministry of Defence. ${ }^{3}$ Echoing these fears, in 2017 the Russian Defence Ministry deemed Svalbard a potential area for future conflict with Norway, and in consequence NATO. ${ }^{4}$

Carving oceans into zones of national ownership is a recent endeavour, solidified with the United Nations Law of the Sea Conventions (UNCLOS) in the 1970s and 80s. Today, marine resources are gaining attention, as the world continues to seek food, energy and rare earth minerals. ${ }^{5} \mathrm{With}$ this attention, focus has also shifted to maritime disputes, many left unresolved due to limited popular and economic interest when they arose decades ago. ${ }^{6}$ This article grapples with the overarching topic of conflict and dispute management between states at sea. By using one specific case of dispute management between Norway and Russia, we can attempt to better understand factors underpinning maritime conflict management.

Given the potential volatility of events in the FPZ, how have Norway and Russia managed to avoid escalation in the case of crisis? Asking why something has not occurred - i.e. outright conflict in the FPZ - is inherently more difficult than asking why something has occurred. ${ }^{7}$ This question is worth asking, however, in order to improve our understanding of the complexities concerning this maritime dispute, which involves resource management in the context of larger security concerns. In turn, a study of this particular issue can enable us to better understand conflict management at sea.

This article is based on several years of data collection (2014-2017) through interviews with Norwegian Coast Guard officials, officials at the Ministry of Foreign Affairs and Ministry of Defence in Norway, as well as former Norwegian Navy and Coast Guard officers. It also leans on previous scholarly work concerned with Russia, Norway, maritime disputes, and fisheries. Several scholars have grappled with these issues before - most notably Pedersen ${ }^{8}$, Hønneland ${ }^{9}$, Jørgensen ${ }^{10}$, Molenaar $^{11}$, 


\section{A. Østhagen}

Stokke ${ }^{12}$, Jensen ${ }^{13}$, and Anderson. ${ }^{14}$ Others have looked at specific incidents and/or agreements in the Barents Sea. ${ }^{15}$

Whereas previous scholarly work has explicitly focused on the legal status of Svalbard and its maritime zones, or looked at managing fisheries in cooperation with Russia, this article brings forth new knowledge by examining the specific incidents that have taken place in the FPZ and attempts to outline why they have been kept at a limited level. Also, by leaning on recently published material by former Norwegian Coast Guard Chief Skram ${ }^{16}$, as well as in-depth interviews with several relevant actors in the Norwegian Military and Government ${ }^{17}$, it adds new empirical understanding to an issue of utmost relevance to Norwegian-Russian relations specifically, and Arctic governance generally.

The article omits, however, Russian perspectives on dispute management in the Svalbard Zone. Norway is the principal authority in the FPZ, and understanding decisions made and attitudes towards infringements by vessels from other countries by the Norwegian authorities is key to understanding why conflict has been kept at a limited level. This is what this article aims to do, while recognising that this is just one piece of the puzzle, albeit a crucial one. The purpose of this article is therefore not to offer a complete overview of all facts, views and details pertaining to the FPZ. Instead, it aims to discuss conflicts between states within the maritime domain in general, using Norwegian approaches to incidents in this maritime zone as a specific case.

The next step would then to be to perform a similar study of Russian perceptions and attitudes towards dispute management and compare these with findings put forth here. Some scholars have already provided insights into general Russian Arctic development, investment and strategies. ${ }^{18}$ These would thus provide an initial starting point for such an analysis, and are also of relevance to this study.

The argument put forth is that from a Norwegian perspective, Norwegian and Russian cooperation is based on both mutual interests and the socializing effects of cooperative mechanisms, which in turn are key to avoid escalation in crisis-scenarios. Yet, we cannot disregard the self-interest that underpins the formation of venues where actors from both states meet, which in turn can be subject to change. In sum, we need to recognise how a combination of economic interests and the effects of socialisation have enabled Norway and Russia to keep conflict levels low, when incidents at sea have occurred.

In the following section, our understanding of conflict between states (including theories on conflict escalation) are outlined. Then the case itself is described, before we embark on a discussion concerned with both the case and the larger idea of conflict management at sea.

\section{Conflict between states}

Conflict is a natural part of society. It describes a situation where two or more actors hold incompatible goals. ${ }^{19}$ Despite common usage, the term does not 
entail outright hostility or war. As described by the SAGE Handbook of Conflict Resolution: "conflict is normal, ubiquitous, and unavoidable". ${ }^{20}$ Galtung, in the 1960s, conceptualised conflict as a triangle between contradiction (incompatibility of positions), behaviour (towards the conflict), and attitude (perceptions about the opposing parties). When all dimensions are present and interacting, conflict occurs. ${ }^{21}$ 'International conflict' is international by virtue of the parties present in the conflict, usually states. These conflicts are often marked by issues pertaining to sovereignty, nationhood, identity and security, making them prone to rapid escalation and potentially catastrophic consequences. ${ }^{22}$ Bercovitch, Kremenyuk, \& Zartman $^{23}$ borrows from Mitchell ${ }^{24}$ and categorises the issues over which states engage in conflict as "(a) issues of resources, (b) issues of sovereignty, (c) issues of survival, (d) issues of honour, and (e) issues of ideology". Others have highlighted the difference between conflict over material interests and conflict over human needs such as security, identity and recognition. ${ }^{25}$

When conflict occurs, its cycle consists of (1) emergence, (2) escalation, (3) attempts to manage the conflict, and (4) resolution of the conflict itself. ${ }^{26}$ Emergence of the conflict takes place when an event or an incident brings the incompatible interests between actors to the agenda. This might happen through deliberate action by actors seeking to gain from the conflict, or by uncoordinated events that highlight the conflict of interests. ${ }^{27}$ When a conflict escalates, it moves from a limited dispute to an incident which can have larger ramifications, as the severity of the conflict grows. ${ }^{28}$ We can roughly envision this as a scale, from 'rhetoric and statements' to 'limited action and threats', and finally to 'destructive actions and outright hostility'. ${ }^{29}$ Escalation is driven by interaction between the competing parties. As Schelling argues ${ }^{30}$, the point of escalation is to convince your opponent to back down, as the "cost" of further escalation is deemed too high. Escalation thus becomes a game of "competitive risk taking". ${ }^{31}$ This relates to the concept of a 'crisis'. A crisis is generally understood as one stage in a conflict with a limited time-span, which contributes to escalation. Holsti describes a crisis consisting of three factors: the issue at hand, the rationale for tension, and the relevant actions taken by the actors. ${ }^{32} \mathrm{~A}$ crisis is (1) unanticipated, (2) perceived as a great threat to the actors involved, (3) perceived as having a limited time frame, and (4) perceived as having the potential for disastrous consequences if left unmanaged. ${ }^{33}$

Moving into the cycle stages of conflict management and resolution, there has been considerable debate in the literature on where to focus efforts when attempting to settle conflict between states. There is a crucial distinction between conflict management - where the underlying problem is not solved and management options are sometimes introduced by third parties - and conflict resolution, which goes to the root of the problem at hand. Conflict resolution is consequently "the process whereby institutional and policy options are discovered that meet the needs of the parties, thus establishing the basis for a resolution of the conflict". ${ }^{34}$ 


\section{A. Østhagen}

For the purposes of this limited case study we can roughly distinguish between rationalist and ideationalist scholars when discussing conflict escalation, management and resolution. Rationalist approaches within international relations place emphasis on the goal-seeking rational behaviour of states, driven and constrained by material factors as well as institutional structures. ${ }^{35}$ For some of these scholars, conflict is a natural part of international affairs, where states seek to optimise their outcomes vis-à-vis each other in the international system. Cooperation (between states) is inherently a product of conflicting interests and/or policies, which in turn are brought into alignment. Conflict thus provides the platform for potential cooperation. States are the relevant actors, as they engage in bargaining and cost-benefit calculations according to fixed preferences in line with the "logic of consequences". ${ }^{36}$ Institutions - as tools set-up by states to manage potential disputes - are rational design consequences of states' interests and a result of a bargaining process between the same states. ${ }^{37}$ Scholars thus argue that if the dispute at hand is of material character, it should be easier to reach pareto-optimal solutions where each party accepts a negotiated outcome. ${ }^{38}$

Alternatively (or additionally), an ideationalist approach takes into consideration ideational factors in international politics. ${ }^{39}$ These include the conceptualisation of identity, the role of historical images, and the mutual constitutive and socialising processes that occur amongst actors operating on an international issue. ${ }^{40}$ Outcomes are thus not only a result of a bargain or negotiation; they are constructed, constituted by actors' interactions. States develop a mutual understanding of what constitutes a 'fair' result when managing their ongoing dispute. This mutual understanding is essential in determining the scope of possible outcomes between the states in question.

One ideational approach that explicitly examines cooperation and conflict is the notion of 'track two diplomacy'. Some contribute the term to the article Foreign Policy According to Freud by Davidson and Montville in 1982, which examined psychological dimensions to conflict resolution. ${ }^{41}$ The authors argued that psychological barriers are the main hindrance to dispute settlement, and if removed or reduced "the contending parties create new possibilities for negotiations". ${ }^{42}$

A core concern is how to measure and separate various causal mechanisms, given the elusive character of some of the ideational concepts. ${ }^{43}$ As Johnston points out, constructivists have a challenge explaining outcomes where realpolitik offers plausible arguments. It is not enough that socialisation theory is able to explain instances where rationalist theories fall short. It should also be able to prove how actors with realist mind-sets are socialised to forgo these conceptions, using cooperation as the vehicle or mechanism for this socialisation. ${ }^{44}$ As Kelman argues: "[ $\mathrm{t}$ ] he hallmark of social interaction is that each participant tries to enter into the other's perspective and take the other's role, thus gaining an understanding of the other's concerns, expectations, and intentions." 45 Kaye also argues that "diplomacy is not just about producing negotiated outcomes but also about influencing how others think". ${ }^{46}$ 
The starting point of operationalising track two diplomatic processes concerned with 'low-level' cooperation is therefore to lean on the conceptualisations made above regarding the formation and constitution of interests. In contrast to rationalist literature, conflict resolution within this approach is less concerned with conflict "resolution", and more concerned with the "transformation" of the actors involved. ${ }^{47}$

In sum, conflict is inherent to interaction between states at the international level. There are several theories that highlight both what states engage in conflict over, as well as how conflicts escalate and, at times, are resolved. Rationalist approaches focus on preferences, bargaining and pareto-optimal outcomes. Actors adhere to a "logic of consequences". Ideationalist approaches revolve around the idea that interests and outcomes are constituted, not set. Interaction between actors can change the interests of the same actors through socialisation and a "logic of appropriateness". ${ }^{48}$ Naturally, this rough separation does not attempt to do justice to the whole range of literature concerning conflicts between states and how to approach a study of these. There are additional theories with a postmodern outlook that critically examine language, power structures, gender, and/or capital, which have not been reviewed here. ${ }^{49}$ At the same time, the purpose of this article is not to question or advance current theories concerned with conflict. Instead, the aim is to improve our understanding of one specific dispute in the Arctic by utilising some of the rough tools provided in the review given in this section. Thus, we now turn to the dispute at hand.

\section{Dispute Management: The Svalbard Zone}

In the post-World War II period, Norway and Russia have been on opposing sides with regards to security and military alliances. Norway has hinged its security on membership in NATO and its bilateral relationship with the United States, with Russia perceived as the primary security challenge. ${ }^{50}$ For Russia, albeit important given the NATO-Russia relationship, Norway constitutes just one out of several neighbours where security issues might arise. ${ }^{51}$ The Barents Sea has been central in the relationship between these two countries. It is a maritime domain integral to the security of both states, as well as to regional economic development in North Norway and North-West Russia respectively.

\subsection{The Svalbard Zone}

The dispute in focus here concerns the waters around the Svalbard archipelago to the north of the Norwegian and Russian mainland. ${ }^{52}$ Norway was granted sovereignty over the archipelago with the Svalbard Treaty, signed in 1920 in Paris, which came into effect in 1925. The Treaty gives nationals from the signatory countries the right to live and work on the islands, while it places some limitations on Norway's ability to tax and use Svalbard for military purposes. ${ }^{53}$ The latter restriction complicates the use of military equipment, yet not when the military is performing civilian tasks. The Norwegian Coast Guard makes use of Longyearbyen for bunkering 


\section{A. Østhagen}

and other civilian purposes. Similarly, although the Norwegian Government has restricted the use of Longyearbyen airport to civilian aviation only, military aircraft can use it when performing civilian tasks such as search and rescue and oil spill response. ${ }^{54}$

Norway and Russia established their 200-nautical mile EEZs in 1976 and 1977, respectively. After establishing its EEZ in the Barents Sea, Norway decided to establish a FPZ around the Svalbard Archipelago in 1977. Norway argues that the 200mile maritime zone around Svalbard is not covered by the Treaty, and thus a regular EEZ where Norway has sovereign rights. ${ }^{55}$ Other countries, however, claim that the principles of the Svalbard Treaty should apply to the 200-mile zone, even though only territorial waters were explicitly stated when the Treaty was formalised in 1920 . This reading of the Treaty means that Norway under articles 2 and 3 cannot discriminate between Norwegian nationals and nationals of the other signatories when it comes to economic activity in the maritime zone. A third approach is to claim that neither the Treaty nor Norwegian rights apply to the zone, in turn deeming the zone around the archipelago international waters. ${ }^{56}$

To avoid an outright challenge to the Norwegian claim, and to protect and manage what is the central nursery area for the Northeast Arctic cod stock, the Norwegian government established the FPZ in $1977 .{ }^{57}$ So far the other Treaty signatories have accepted this, although Russia and Iceland in particular have been outspokenly critical of what they perceive of as discrimination toward their fishing vessels by the Norwegian Coast Guard. ${ }^{58}$ Norway also claims that the Svalbard Treaty does not apply to the continental shelf around the archipelago. Norway argues that Svalbard does not have a continental shelf in its own right (politically), and that the continental shelf is subject to Norwegian sovereign rights. ${ }^{59}$ Although other countries dispute this as well, the scope of the Treaty concerning both the maritime zone and the continental shelf has never been tried before an international court. In 2006, Norway submitted its extended continental shelf claims in accordance with UNCLOS, and the Commission on the Limits of the Continental Shelf gave its final recommendations in 2009. ${ }^{60}$ The Commission found that Norway's continental shelf in relation to Svalbard extends beyond 200 nautical miles, yet did not discuss whether or not the Treaty holds relevance for the shelf areas around Svalbard. In 2015, the Norwegian Government launched the $23^{\text {rd }}$ licensing round for oil and gas exploration and production, which included some blocks in what could be Svalbard's continental shelf. Russia delivered a diplomatic protest, and so far, no activity has commenced in these blocks. ${ }^{61}$

\subsection{Establishing Cooperation}

In the 1970s, cooperation between Norway and Russia in the Barents Sea developed pragmatically in response to the establishment of the EEZs and the subsequent disputes that arose. An agreement between Norway and the USSR on fisheries in the Barents Sea was completed in 1975, and the first Joint Fisheries Commission between the two countries convened in 1976. The Commission's role is to ensure 
sustainable management and exploitation based on scientific advice of the four stocks that are considered common in the Barents Sea, namely North-East Arctic cod, haddock, capelin, and Greenland halibut. ${ }^{62}$ This has become the primary mechanism to solve - or at a minimum manage - disputes concerning fisheries in the Barents Sea.

Similarly, as petroleum exploration in the Barents Sea expanded and the Cold War ended, Russia and Norway agreed on an oil spill agreement in 1994. It included developing joint contingency plans and procedures for notification in the event of an oil spill. ${ }^{63}$ It is reckoned that oil spills will drift eastwards due to the currents in the Barents Sea, and an oil spill in the Norwegian part is therefore likely to end up on the Russian shoreline. Joint exercises have been conducted between the two countries, where the crossing of borders by personnel constitute a core element. ${ }^{64}$ Similarly, search and rescue cooperation was initially based on an agreement from 1956, which was renewed in 1988 and $1995 .{ }^{65}$ As with oil spill prevention and response, bilateral cooperation entails sharing of information and mechanisms for support in the case of a request from the other country.

Another area of bilateral cooperation that has developed with the growth of maritime traffic has been the exchange of information between the various vessel traffic services. In 2006, Norway and Russia agreed on strengthening maritime safety measures. Based on this, Vardø VTS (Vessel Traffic System) and its Russian counterpart in Murmansk signed an agreement on mutual sharing of information concerning high risk traffic venturing between Murmansk and along the North Norwegian coast, implemented in 2013. ${ }^{66}$ Information on high risk vessels passing through or proceeding to and from ports and anchorages within the Barents area are shared through a joint traffic management information system. ${ }^{67}$ Similarly, a Norwegian-Russian system named Barents SRS (Ship Reporting System) was implemented in 2013. It requires high risk vessels to register when sailing in waters stretching from Lofoten in North Norway to Murmansk in Russia. ${ }^{68}$

Practical cooperation between Norway's and Russia's coast guards started in the early 1990s. ${ }^{69}$ After the Soviet Union dissolved, fishing vessels started overexploiting the Barents cod stock and in 1992 the Joint Fisheries Commission expanded their mandate to include control measures. Routines for sharing information on catches were subsequently established..$^{70}$ By 2000, cooperation had further developed and a Memorandum of Understanding outlining a number of cooperative measures was signed between the countries and their coast guards. ${ }^{71}$ An additional - and substantial - part of the coast guard cooperation involves the mutual exchange of fisheries inspectors and operational personnel. Central to this cooperation is that coast guard personnel meet with their Russian or Norwegian counterparts to learn procedures, exchange experiences and establish personal relations.

In sum, these various measures of relatively in-depth cooperation have derived from the need to jointly manage fish stocks in the Barents Sea to the benefit of both Norway and Russia. Maritime cooperation has expanded to deal 


\section{A. Østhagen}

with a growing number of challenges: initially the increase in unregulated fisheries and subsequently a wide range of tasks relating to search and rescue, oil spill prevention and response, and management of marine resources. The Joint Fisheries Commission in particular is a central tool for managing fisheries between the two countries, often described as the backbone of bilateral cooperation in the Barents Sea. ${ }^{72}$

\subsection{Crises and Escalation}

Albeit well managed, there have been incidents in the Barents Sea that have had the potential to escalate and take on the characteristics of a 'crisis'. Tensions between Norway and Russia have arisen in connection with Norwegian arrests of Russian vessels in the FPZ, and the potential escalation that can occur from a fisheries incident to a state-state incident. It is customary that Russian fishing vessels inspected by the Norwegian Coast Guard in the FPZ refuse to sign the inspection documents as a gesture to highlight Russia's refusal to recognize Norwegian authority in the Zone although they allow the Norwegian Coast Guard to perform inspections of the vessels. ${ }^{73}$ The Russian Coast Guard has, on occasion, suggested that Norway and Russia conduct joint fisheries inspections in the FPZ around Svalbard. ${ }^{74}$ Such cooperation would, however, challenge Norwegian sovereignty and authority in the FPZ, and the Norwegian Government has declined all such proposals. ${ }^{75}$

Up until the turn of the millennium, Norwegian enforcement of fisheries regulation in the FPZ was relatively constrained compared to the Norwegian EEZ. ${ }^{76}$ In the late 1990s, however, scientists reported that fish stocks were in decline and quotas had to be reduced to achieve sustainable fisheries. ${ }^{77}$ Calculations show that in the period 2002-2005 alone, Russian fishing vessels exceeded their quotas in the Barents Sea by around 100000 tons annually. ${ }^{78}$ At the same time, the Norwegian Coast Guard Act (Kystvaktloven) was passed in 1997, with an increased focus on competence enabling measures in the Coast Guard. ${ }^{79}$ From around 2000 onwards, there was a shift in enforcement policy in the FPZ. Increased competence in the Coast Guard in combination with growing concerns over the state of the fish stocks, led to stricter enforcement of the regulatory regime. ${ }^{80}$

The first arrest of a Russian fishing vessel that marked a more stringent enforcement regime came in 1998, with the attempted arrest of the Novokuybyshevsk. Parts of the Barents Sea were closed for fisheries in 1998 due to concerns over unsustainable fishing, and the vessel was found to be in violation of several regulations. ${ }^{81}$ As the Novokuybyshersk was towed by the Norwegian Coast Guard towards Tromsø, there were reports of a Russian Navy vessel leaving the Kola Peninsula headed west, and Russian airplanes were seen passing over the Norwegian Coast Guard vessel. These actions were interpreted as reactions to the Norwegian arrest; the first of its kind in the FPZ. In the end, the issue was resolved through diplomacy and the vessel was released before reaching Tromsø after instructions from the Norwegian government in dialogue with its Russian counterparts. ${ }^{82}$ 
Three years after the Novokuybyshevsk incident, in 2001, the Russian vessel Chernigov was arrested. As with the Novokuybyshevsk, Russian naval activity on the Kola Peninsula was registered, although there was no confrontation at sea. ${ }^{83}$ The arrest of Chernigov - the first Russian vessel from the FPZ to be brought all the way to Tromsø - led to diplomatic protests from Russia, as well as the presence of a Russian Navy vessel - Severomorsk - in the FPZ the following year, presumably to inspect and safeguard Russian fishing vessels. As Åtland and Bruusgaard write: "[t]his rare Russian show of force was apparently meant to send a signal to political decisionmakers in Norway". ${ }^{84}$ In the three years that followed (2002-2004), no arrests of Russian vessels took place in the FPZ.

In 2005, however, Norwegian fisheries inspectors from the Coast Guard boarded the Russian vessel Elektron, after it had been under surveillance for some time. After severe infringements were uncovered, the trawler was arrested and escorted towards Tromsø for the Norwegian Police to continue with the prosecution. The captain of Elektron, in agreement with its Russian owners, had other plans and decided to flee with the two Norwegian fisheries inspectors on-board. ${ }^{85}$ From October 16 until October 19, four Norwegian Coast Guard vessels, as well as a maritime surveillance aircraft and several helicopters, closely tailed the trawler as it headed for Russian waters. The Norwegian Government considered using military force to halt the vessel by boarding it. In the end, bad weather was blamed for not following through with the boarding. ${ }^{86}$ It is also highly likely that Norwegian authorities were concerned with the escalation effects such actions could have vis-à-vis Russia. ${ }^{87}$

The Elektron-incident was widely publicised, with coverage on Norwegian national television. Fermann and Inderberg argue that this was a part of a conscious strategy by the Norwegian authorities to gain sympathy for its policies and ensure public support. ${ }^{88}$ If we refer to the definitions previously laid forward concerning crises and conflict cycles, it seems apparent that this affair had all the characteristics of a crisis. The incident was unanticipated (1), perceived as a great threat to the actors involved (2), within a limited timeframe (3), and had the potential to cause serious damage in the relations between Norway and Russia (4). It is significant that this incident did not only concern fisheries management, it also took part in the larger context of the disputed regime concerning Svalbard's maritime zone and attempts by Norway to establish a clear legal precedent in the same area.

On October 20, the two fisheries inspectors were released to the Norwegian Coast Guard by the Russian Border Service (its coast guard), which had arrived to escort Elektron to Murmansk after "intense dialogue" between the Russian and Norwegian governments. ${ }^{89}$ Russian reactions to the initial arrest were less severe than in 2001 , as dialogue was chosen ahead of protests. The incident has subsequently become seen an example of a small-scale dispute managed well by both Norway and Russia. As described by former Norwegian Coast Guard Chief Skram, the fact that Norway was considered an "OK" neighbour in Russia, in tandem with the recognition that there needs to be a rule-based regime concerning fisheries in the Barents Sea, helped the 


\section{A. Østhagen}

two countries manage this particular crisis. ${ }^{90}$ At the same time, the incident led to questions being asked about the division between civilian and military tasks in the Norwegian Coast Guard, as well as how best to manage such volatile incidents in the future. ${ }^{91}$ After Elektron, the Norwegian Coast Guard attempted to develop new ways of settling fines at sea instead of having to bring fishing vessels all the way to Tromsø; a journey that entails considerable costs to the owners of the vessels. ${ }^{92}$

In 2010, Norway and Russia reached agreement on the maritime boundary dispute in the Barents Sea ${ }^{93}$. However, actors in Russia were claiming that the deal was too favourable to Norway. ${ }^{94}$ There was also fear that Russian fishermen could potentially be excluded from waters they had access to in the Norwegian EEZ, if Norway at one point decided to halt cooperation on quotas. Echoing these fears, as the maritime boundary was implemented in 2011 , there was an increase in the number of arrests of Russian fishing vessels in the FPZ. In an untimely turn of events, the Norwegian Fisheries Minister had announced the same year that Norway would not tolerate the practice of discarding fish, an issue that was receiving increased attention in Norway as well as in the EU with its reform of the EU Common Fisheries Policy. ${ }^{95}$ Discards were a growing problem in the Barents Sea fisheries. ${ }^{96}$

The arrests of Russian fishing vessels that year - five in total - peaked in another crisis on September 28, 2011, as the Norwegian Coast Guard attempted to arrest the Russian trawler Sapphire II in the FPZ. The captain resisted the arrest and kept in dialogue with a Russian state vessel, which was nearby. Eventually Sapphire II was towed to Tromsø and charged, albeit with the Russian state vessel tailing until they reached the Norwegian EEZ. ${ }^{97}$ In the Russian media, there were strong reactions against what was described as aggressive and discriminatory behaviour by the Norwegian Coast Guard toward Russian vessels. ${ }^{98}$ Russia also delivered a protest to the Norwegian Embassy in Moscow. This in turn influenced the Joint Fisheries Commission in 2011 and 2012, hampering negotiations on quotas and access. In the end, however, the two countries reached agreement on procedures for enforcing the ban on discarding fish, and worked on more harmonised guidelines for inspecting fisheries. ${ }^{99}$ Since Sapphire II, there have been no similar arrests made of Russian fishing vessels in the FPZ. At the same time, the practice of settling arrests at sea has increased.

In March 2014, Russia annexed Crimea, and relations between Norway and Russia became strained as Norway followed the EU and the United States sanctioning Russia over its actions in Ukraine. In terms of consequences for disputes in the FPZ, it is hard to pinpoint exact effects. As the Norwegian Coast Guard highlights, the larger international dispute has not had any direct effect on Norway-Russia cooperation concerning coast guard affairs in the Barents Sea. ${ }^{100}$ At the same time, there has been an increased amount of attention given to the potential for conflict in the Barents Sea. ${ }^{101}$ Both countries deem this to be a region of significance, as highlighted by a report by the Russian Defence Ministry in 2017 listing Svalbard and its 
maritime zone as potential areas for confrontation between Russia and NATO. ${ }^{102}$ Following that report, a controversial Norwegian blog concerned with defence aldrimer.no - reported that Russia had simulated an invasion of Svalbard during its military exercise Zapad in 2017. ${ }^{103}$ Albeit not surprising given Russian military strategies in the north, ${ }^{104}$ this was refuted by both the Norwegian Minister of Defence and the Head of the Norwegian Military Intelligence Service. ${ }^{105}$ Whether or not it was accurate, it sparked a brief debate amongst Norwegian politicians and defence analysts, and highlights the underlying fear that Svalbard might become an arena for conflict with Russia. Hence, we could speculate that there have been efforts made on both the Norwegian and Russian side to avoid confrontation over the FPZ from 2014 onwards, given the larger security concerns that such a dispute would entail.

In sum, the FPZ around Svalbard has been the domain in which several small-scale incidents have occurred between Norway and Russia, or more accurately, between the Norwegian Coast Guard and Russian fishing vessels. None of these incidents have spiralled out of control, although some have taken on a state-to-state dimension, as Russian authorities reacted to Norwegian actions. Yet, both countries have managed to avoid further escalation and solved the issue at hand. The question then is why? What are the factors underpinning this relative stability?

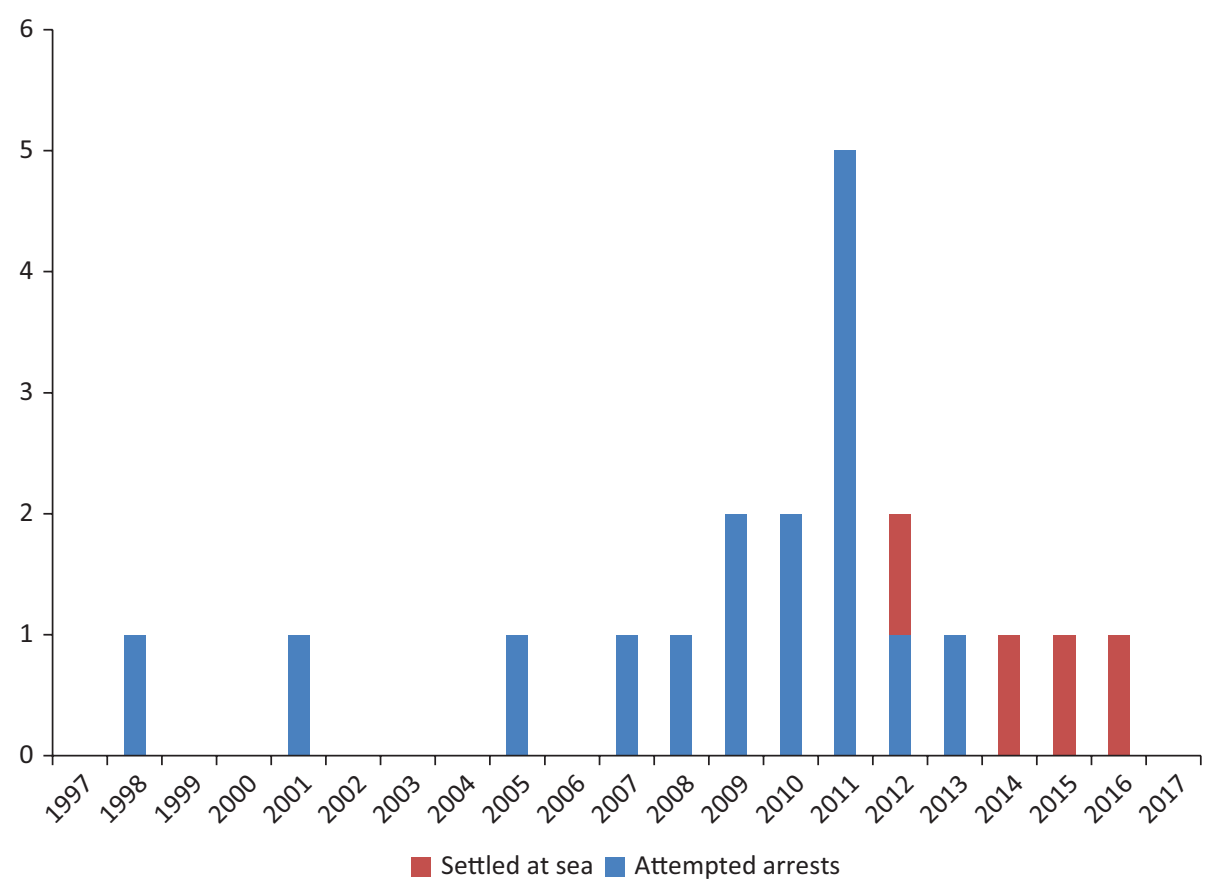

Table I. Arrests of Russian fishing vessels in the FPZ between 1997 and 2017. Note those that were settled at sea. ${ }^{106}$ 


\section{A. Østhagen}

\section{Conflict Management in the FPZ}

First, we can attempt to pinpoint to what extent conflict situations in waters around Svalbard have escalated beyond only political statements. A more stringent enforcement of regulations in the FPZ was pursued from 1998 onwards. Russia responded to arrests by the Norwegian Coast Guard with diplomatic protests and a show of military force. In some instances, the arrest of a single trawler also spilled over into the Joint Fisheries Commission and hampered cooperation. It seems, given the two countries' willingness to use force (or the threat of the use of force), that the incidents on their own have had the potential to escalate from a win-win situation to a situation where one or both parties stand to lose.

Specifically concerning Chernigov in 2001, Elektron in 2005, and Sapphire II in 2011, the arrests themselves and the larger issue concerning Norwegian rights in the FPZ, escalated to the extent that threats were implicitly stated through military actions, while certain actors were outspokenly critical of the other party. At least, this was the case amongst Russian fishermen and their related shipowners, as well as amongst former fisheries officials and regional representatives in Murmansk. ${ }^{107}$ At the national level, however, statements from both Norway and Russia have been constrained. Despite Russian complaints against Norwegian actions in the FPZ, these have not escalated beyond rhetoric and statements. Therefore, although fluctuating as arrests have occurred, the overarching conflict over the maritime zone around Svalbard has not escalated, making it manageable for both the Russian and the Norwegian governments.

Asking why this is the case, however, is a harder nut to crack. If we return to the initial conceptions of why and how states engage in and resolve conflict, we can identify some key factors underpinning the relatively stable relationship between Norway and Russia. First, rationalist ideas of power, coercion and interests help frame the FPZ in the larger context between these two states and their regional and global positions. Norway's membership in NATO and outspoken policy of ensuring US support in case of sovereignty threats, ${ }^{108}$ come into play. Yet, deterrence does not help explain how and why Norway and Russia continue to establish new forms of low-level cooperation in the Barents Sea, and how the two countries solve incidents when they do occur. We therefore must move from the systemic level to the immediate issues at hand between the two actors.

According to rationalist logic, cooperation can be the product of discord. In other words, states cooperate when they disagree. Sometimes formalisation and institutions are needed to overcome the self-help tendencies of the international system. Along this line of argumentation, cooperation between Norway and Russia concerning shared fish stocks, oil spill response, search and rescue, and ship traffic management are formalised arrangements set up to manage potential areas of discord. Along the same line of argumentation, the Barents Sea maritime boundary agreement in 2010 was a result of interests between the two states converging sufficiently. ${ }^{109}$ 
In other words, the reason why Norway and Russia manage to keep crises from escalating further, is mutual interest in preserving aspects of their cooperation; cooperation that benefits both parties. This relates to multiple issue areas. Concerning resource management, Russia is assumed to be satisfied with the current quota scheme, in contrast to what might be achieved if an actual debate over the status of the FPZ took place. ${ }^{110}$ Concerning the UNCLOS-regime, both parties benefit from a stable legal regime in the FPZ specifically, but also in the Arctic at large. ${ }^{11}$ And concerning national security, both parties have an interest in low levels of conflict for fear of coercive efforts by other actors within and outside the Barents/ Arctic region. ${ }^{112}$

The interests that drive cooperation might, however, be subject to change (over time). We can see changes taking place within all the issue-areas addressed: as climate change continues to alter the marine resource base in the Barents Sea; as external actors challenge the validity of the UNCLOS-regime in the Arctic; or as the power relations between various actors fluctuate. The institutions set up to manage cooperation are also challenged and questions of institutional resilience become salient: how will cooperative mechanisms adapt as conditions influencing the premise for cooperation change? ${ }^{113}$

For example, as Norway and Russia struggled to reach agreement on a reduction of annual quotas for the Barents Sea in the early 2000s, several institutional measures were taken. In 2002, a harvest control rule was introduced in the Joint Fisheries Commission to set quotas according to scientific advice while also limiting fluctuations from year to year. This has been described as the most important change in the work of the Commission, removing a source of friction between the two states (which had spill-over effects into the FPZ). ${ }^{114}$ Another adaptation (or innovation) was the development of a port state control regime amongst the North East Atlantic coastal states, which improved information concerning quotas and port deliveries, removing accusations of overfishing and unreliable information. ${ }^{115}$ Similarly, the measures taken in 2012 to harmonise rules for inspections of fishing vessels that were taken after the Sapphire II incident removed another source of friction in the FPZ.116

The rationalist approach to dispute management in the international domain provides a functional answer: institutions are set-up for a purpose and will (must) adapt as conditions for their existence alter. The reason why Norway and Russia have managed to avoid further escalation of potential crisis in the FPZ - without settling the overarching dispute concerning the status of the maritime zone - is because their interests are sufficiently aligned within several related domains and issue areas. If interests remain converged, and/or institutions like the Joint Fisheries Commission can enable convergence through negotiations, incidents are unlikely to escalate into actions that can threaten the larger bilateral relationship.

This does not, however, capture the whole proverbial elephant. As emphasised by officials in the Norwegian Coast Guard ${ }^{117}$, former Coast Guard officers, ${ }^{118}$ and 


\section{A. Østhagen}

multiple scholarly works written on the management of shared fish stocks in the Barents Sea, ${ }^{119}$ the individual level constitute a core element of conflict management in the Barents Sea. This concerns ideational factors, meaning the influence and importance of ideas and social interactions, on top of what we can observe through interest alignment and rational bargaining theory. ${ }^{120}$

In the Svalbard Zone, some key elements stand out. The importance of dialogue during a crisis is given much of the credit for solving incidents between the Norwegian Coast Guard and Russian fishing vessels. This includes communication between the Coast Guard and Russian trawlers (including the use of Russian interpreters); between the Norwegian Joint Military Headquarters and the Chief of the Russian Northern Fleet at Severomorsk; and between the negotiating groups in the Joint Fisheries Commission. ${ }^{121}$ Having various means of communicating, and keeping channels open as a crisis is unfolding, constitute central elements in the management of conflict in the FPZ. ${ }^{122}$ This can be linked to the notion of 'track two diplomacy', albeit without an immediate large-scale international crisis as an impetus. Still, instilling so called low-level or 'soft' dialogue in addition to other more formal channels of communication, have - in this case - provided an effective approach to conflict management. ${ }^{123}$

This concerns the larger concept of personal relations, as social contact between two or more individuals representing different sides in a dispute. The theory of socialisation emphasises not only the communication component, but also the fact that a change occurs between the parties. Norms (expected behaviour) socialise (change) actors according to a logic of appropriateness. ${ }^{124}$ By interacting regularly with the same individuals on the same issues (fisheries, quotas, inspections) over time, mutual understanding emerges as the individuals themselves better comprehend the position of the other party. As the Norwegian Coast Guard puts it:

\footnotetext{
"When we cooperate with Russian officials, Russian fishermen subsequently learn about our rules and procedures. This lowers the chance of serious violations at sea. Moreover, we learn about the Russian approach to the same issues. This helps harmonise rules and regulation across the two countries." 25
}

In turn, compromise is reached. As Hønneland and Jørgensen describe the "culture of cooperation" in the Barents Sea: "[a] common feature in these cases [fisheries cooperation] is that the parties met exactly in the middle". ${ }^{126}$ Crucially, this 'middle' is not given, it is constructed through dialogue and communication. ${ }^{127}$

Moreover, personal relations have formed the basis for the institutionalisation of some of these mechanisms. This concerns the exchange of coast guard officers from Norway and Russia, as well as the formalised sharing of information and annual meetings between the Chiefs of the coast guards. This institutionalisation and its relevance for the issues at hand in the Barents Sea at large, and the FPZ specifically, played a central part in sheltering the coast guard cooperation from sanctions and restrictions put in place between Norway and Russia in 2014. ${ }^{128}$ 
There is thus a feedback loop taking place between institutionalisation and personal interactions.

This article does not attempt to outline a monocausal explanation for success in maritime dispute management. Instead, the aim is to showcase how multiple explanations emphasising different aspects of conflict relations contribute to the outcome. In sum, several factors concerning the dispute in the Svalbard Zone help explain why it has been managed adequately in the context of a larger quarrel.

\section{Conclusion: conditions for success?}

This article has only examined one case that includes multiple incidents. Still, some relevant conditions have become apparent, particularly in the incidents concerning the Russian vessels Chernigov, Elektron and Sapphire II. Vasquez and Valeriano describe a conflict as spiralling when it is infused with symbolic qualities. ${ }^{129}$ Initially, one would imagine that maritime disputes - whether concerned with fishing rights or boundaries - would be a simple matter of delineating rights and ownership, given the tangible character of such disputes. Yet, it seems apparent that as soon as a maritime dispute reaches the political agenda, there are actors who benefit from infusing it with intangible dimensions such as 'national pride' and 'being cheated from what is ours'. ${ }^{130}$

Officials in Murmansk and representatives from the fisheries industry have attempted to frame the dispute in the larger security relations between Norway and Russia, arguing that Russia is weak and does not protect its rights (compared to times under the USSR). ${ }^{131}$ As Atland and Bruusgaard show ${ }^{132}$, these attempts at "securitisation" were not successful in spurring the Russian government into escalating actions. Yet, they highlight how maritime disputes are not devoid of the intangible and symbolic elements that can lead to conflicts escalating beyond the dispute at hand. Albeit outside the scope of this article, it is worth noting that similar attempts to politicise or even securitise maritime disputes were perhaps more successful during the Cod and Turbot Wars, or more recently in the South China Sea. This shows how maritime disputes are not devoid of the intangible and symbolic elements that can lead to conflicts escalating beyond the initial matter at hand.

Maritime disputes are on the one hand more elusive, or at least less place-bound, than conflicts on land, given the characteristics of the maritime domain. On the other hand, disputes can take on some of the same intangible characteristics as disputes on land. Despite initially being more concerned with tangible questions of resource delimitation and 'who owns what', disputes at sea can still be subject to the escalating dynamics of disputes more generally. ${ }^{133}$ It is within this space that dialogue and communication, and possibly socialisation, stand out. As this case has highlighted, the ongoing dispute between Norway and Russia in the Arctic has been managed primarily by communicating with the counterpart. At the same time, behind the amicable relations between coast guard and military officials on 


\section{A. Østhagen}

both sides looms the larger security relationship that both states are engaged in, and their numerous reasons to avoid escalating tensions both bilaterally and regionally.

This in turn can also be explained by the rationale driving much of the expansion in cooperation between Norway and Russia, namely the inherent win-win opportunities for states at sea. These come from the nature of tasks concerned with emergency preparedness and response, as there are limited capabilities and resources present in this vast maritime domain. Cooperation on assistance in the case of an emergency is relatively simple, spurred by the characteristics of the maritime. Another area of win-win opportunities lies in marine resource management. Primarily fisheries, but also transboundary oil and gas deposits, have strong cooperative elements where it is relatively easy to recognise the need for collaboration across international boundaries.

We must separate between low-level disputes taking place in a maritime domain such as those between Russian trawlers and Norwegian authorities - and larger so-called 'high level' conflicts involving a threat to the state itself. As this case study has highlighted, it has been possible for Norway and Russia to distinguish between these levels. Yet, there is no law of nature that keeps these levels separate, and small-scale disputes do undoubtedly run the risk of escalating beyond their limited realm. Understanding what underpins stable relations is thus central, and the next step would be to flip this study and examine Russian perceptions and approaches to the same dispute.

\section{NOTES}

1. Torbjørn Pedersen and Tore Henriksen, "Svalbard's Maritime Zones: The End of Legal Uncertainty?," The International fournal of Marine and Coastal Law 24, no. 1 (2009): 141-61; Øystein Jensen, Norge og havets folkerett (Norway and Law of the Sea) (Trondheim: Akademia Forlag, 2014), 101.

2. Erik J. Molenaar, "Fisheries Regulation in the Maritime Zones of Svalbard," The International fournal of Marine and Coastal Law 27, no. 1 (2012): 3-58.

3. Norwegian Coast Guard Official I, "Interview: Norwegian Coast Guard Official” (Haakonsvern: October 1, 2017, 2017); Government Official Norway I, "Interview: Official at Ministry of Defence I" (Oslo: October 3, 2017, 2017).

4. Thomas Nilsen, "Kommersant: Russia Lists Norway's Svalbard Policy as Potential Risk of War,” The Independent Barents Observer, October 4, 2017, https://thebarentsobserver.com/en/ security/2017/10/kommersant-russia-lists-norways-svalbard-policy-potential-risk-war.

5. The Economist, "Plucking Minerals from the Seabed Is Back on the Agenda," The Economist, February 2017, https://www.economist.com/news/science-and-technology/21717351fruits-de-mer-plucking-minerals-seabed-back-agenda.

6. Victor Prescott and Clive Schofield, Maritime Political Boundaries of the World (Leiden, NLD: Martinus Nijhoff Publishers, 2004).

7. Ian Shapiro, "Problems, Methods, and Theories in the Study of Politics, or What's Wrong with Political Science and What to Do about It," Political Theory 30, no. 4 (2002): 596-619.

8. "The Constrained Politics of the Svalbard Offshore Area," Marine Policy 32, no. 6 (2008): 913-19; "Endringer i internasjonal Svalbard politikk," Internasjonal Politikk 67, no. 1 (2008): 31-44; "International Law and Politics in U.S. Policymaking: The United States and the 
Svalbard Dispute," Ocean Development and International Law 42, no. 1-2 (2011): 120-35,; "The Politics of Presence: The Longyearbyen Dilemma," Arctic Review on Law and Politics 8 (2017): 95-108.

9. Making Fishery Agreements Work: Post-Agreement Bargaining in the Barents Sea (Cheltenham: Edward Elgar Publishing Limited, 2012); "Kompromisskulturen i barentshavet (the Culture of Compromise in the Barents Sea)," in Norge og Russland: Sikkerhetspolitiske utfordringer i nordomradene (Norway and Russia: Security Challenges in the High North), ed. Tormod Heier and Anders Kjølberg (Oslo: Universitetsforlaget, 2015), 57-68; Russia and the Arctic: Environment, Identity and Foreign Policy (London: I. B. Tauris, 2016).

10. Russisk Svalbardspolitikk (Russian Svalbard Policy) (Trondheim: Tapir Akademiske Forlag, 2010).

11. "Fisheries Regulation in the Maritime Zones of Svalbard."

12. "Managing Straddling Stocks: The Interplay of Global and Regional Regimes," Ocean and Coastal Management 43, no. 2-3 (2000): 205-34; Governing High Seas Fisheries: The Interplay of Global and Regional Regimes (New York: Oxford University Press, 2001).

13. Norge og havets folkerett (Norway and Law of the Sea).

14. "The Status Under International Law of the Maritime Areas Around Svalbard," Ocean Development E International Law 40, no. 4 (2009): 373-84.

15. For example Kristian Åtland and Kristin Ven Bruusgaard, "When Security Speech Acts Misfire: Russia and the Elektron Incident," Security Dialogue 40, no. 3 (2009): 333-53; Svein Kosmo, "Kystvaktsamarbeidet Norge-Russland. En fortsettelse av politikken med andre midler? (Coast Guard Cooperation Norway-Russia. A Continuation of Politics through Other Means?)," Forsvarets Stabsskole (Norwegian Joint Staff College, 2010); Gunnar Fermann and Tor Håkon Inderberg, "Norway and the 2005 Elektron Affair: Conflict of Competencies and Competent Realpolitik," in War: An Introduction to Theories and Research on Collective Violence, ed. Tor Georg Jakobsen, 2nd ed. (New York: Nova Science Publishers, 2015), 373-402; Andreas Østhagen, "High North, Low Politics Maritime Cooperation with Russia in the Arctic," Arctic Review on Law and Politics 7, no. 1 (2016): 83-100.

16. Alltid til stede: Kystvakten 1997-2017 (Always Present: Coast Guard 1997-2017) (Bergen: Fagbokforlaget, 2017).

17. Norwegian Coast Guard Official I, "Interview: Norwegian Coast Guard Official”; Norwegian Coast Guard Official II, "Interview: Norwegian Coast Guard Leadership" (Sortland: November 20, 2017, 2017); Government Official Norway I, "Interview: Official at Ministry of Defence I"; Government Official Norway II, "Interview: Official at Ministry of Defence II" (Oslo: November 28, 2017, 2017).

18. Hønneland, Russia and the Arctic: Environment, Identity and Foreign Policy; Lars Rowe, "Fra Unntakstilstand Til En Ny Normal ('From State of Emergency to New Normalcy')," in Naboer I Frykt Og Forventning: Norge Og Russland 1917-2014 ('Neighbors in Fear and Expectation: Norway and Russia 1917-2014'), ed. Sven G. Holtsmark (Oslo: Pax Forlag, 2015), 628-32; Alexander Sergunin and Valery Konyshev, "Russia in Search of Its Arctic Strategy: Between Hard and Soft Power?,” Polar fournal 4, no. 1 (2014): 69-87, https://doi. org/10.1080/2154896X.2014.913930; Valery Konyshev and Alexander Sergunin, "Is Russia a Revisionist Military Power in the Arctic?," Defense and Security Analysis 30, no. 4 (2014): 323-35, https://doi.org/10.1080/14751798.2014.948276.

19. William J. Dixon, "Third-Party Techniques for Preventing Conflict Escalation and Promoting Peaceful," International Organization 50, no. 4 (1996): 655.

20. Jacob Bercovitch, Victor Kremenyuk, and I. William Zartman, "Introduction: The Nature of Conflict and Conflict Resolution," in The Sage Handbook of Conflict Resolution (London: Sage Publications, 2009), 4, https://doi.org/10.4135/9780857024701. 
21. Johan Galtung, "Violence, Peace, and Peace Research," fournal of Peace Research 6, no. 3 (1969): 167-91; Johan Galtung, Peace by Peaceful Means: Peace and Conflict, Development and Civilization (Oslo: Prio Peace Institute, 1996).

22. Dixon, "Third-Party Techniques for Preventing Conflict Escalation and Promoting Peaceful," 655.

23. "Introduction: The Nature of Conflict and Conflict Resolution," 8.

24. Peacemaking and the Consultants Role (Westmead, UK: Gower Publishing, 1981).

25. John Burton, Resolving Deep-Rooted Conflict:A Handbook (Lanham, MD: University Press of America, 1987); Thomas Diez, Ingvild Bode, and Aleksandra Fernandes da Costa, "Conflict Resolution," in Key Concepts in International Relations (London: Sage Publications, 2011), 10-16, https://doi.org/10.1007/978-1-4419-7771-7.

26. Thomas Diez, Ingvild Bode, and Aleksandra Fernandes da Costa, "Conflict Resolution," in Key Concepts in International Relations (London: Sage Publications, 2011), 10-16; Jacob Bercovitch, Victor Kremenyuk, and I. William Zartman, "Introduction: The Nature of Conflict and Conflict Resolution," in The Sage Handbook of Conflict Resolution (London: Sage Publications, 2009), 1-11.

27. Lisa J. Carlson, "A Theory of Escalation and International Conflict," The fournal of Conflict Resolution 39, no. 3 (1995): 511-34.

28. Thomas Jordan, "Glasl's Nine-Stage Model Of Conflict Escalation,” Mediate.com, 2000, http://www.mediate.com/articles/jordan.cfm.

29. Bercovitch, Kremenyuk, and Zartman, "Introduction: The Nature of Conflict and Conflict Resolution"; Friedrich Glasl, Confronting Conflict: A First-Aid Kit for Handling Conflict (Lansdown: Hawthorn Press, 1999).

30. The Strategy of Conflict (Cambridge, MA: Harvard University Press, 1960).

31. Carlson, "A Theory of Escalation and International Conflict," 513.

32. International Politics: A Framework for Analysis (Engelwood Cliffs, NJ: Prentice Hall, 1995), 328.

33. Holsti, 329; Charles F. Hermann, "International Crisis as a Situational Variable," in International Politics and Foreign Policy: A Reader in Research and Theory, ed. James N. Rosenau (New York: Free Press, 1969), 414.

34. Burton, Resolving Deep-Rooted Conflict: A Handbook, 7.

35. See for example James D. Fearon, "Rationalist Explanations for War," International Organization 49, no. 3 (1995): 379-414; Robert O. Keohane, After Hegemony: Cooperation and Discord in the World Political Economy (Princeton, NJ: Princeton University Press, 1984); Robert O. Keohane and Joseph S. Nye, Power and Interdependence, 4th ed. (Longman, 2012); Stephen D. Krasner, ed., International Regimes (Ithaca, New York State: Cornell University Press, 1983); John J. Mearsheimer, The Tragedy of Great Power Politics (New York: W. W. Norton \& Company, 2001); Andrew Moravcsik, "Taking Preferences Seriously: A Liberal Theory of International Politics," International Organization 51, no. 4 (1997): 229, https://doi. org/10.1162/002081898550536; Kenneth N. Waltz, Theory of International Politics (Boston, MA: McGraw-Hill, 1979); Kenneth N. Waltz, Man, the State, and War (New York: Columbia University Press, 1959).

36. James G. March and Johan P. Olsen, "The Institutional Dynamics of International Political Orders," International Organization 52, no. 4 (1998): 943-69.

37. James D. Fearon, "Bargaining, Enforcement, and International Cooperation," International Organization 52, no. 2 (1998): 269-305; Barbara Koremenos et al., "International Organization Foundation The Rational Design of International Institutions," International Organization 55, no. 4 (2001): 761-99.

38. See for example John. A. Vasquez, "Why Do Neighbors Fight? Proximity, Interaction, or Territoriality," Fournal of Peace Research 32, no. 3 (1995): 277-93; Paul R. Hensel et al., 
"Bones of Contention: Comparing Territorial, Maritime and River Issues," fournal of Conflict Resolution 52, no. 1 (2008): 117-43.

39. As outlined by Jeffrey T. Checkel, "Constructivism and Foreign Policy," in Foreign Policy: Theories, Actors, Cases, ed. Steve Smith, Amelia Hadfield, and Tim Dunne (Oxford: Oxford University Press, 2008), 52-53.

40. Emanuel Adler and Michael Barnett, Security Communities, ed. Emanuel Adler and Michael Barnett (Cambridge: Cambridge University Press, 1998); David Campbell, Writing Security: United States Foreign Policy and the Politics of Identity (Minneapolis: University of Minnesota Press, 1998); Jeffrey T. Checkel, "International Institutions and Socialization in Europe: Introduction and Framework," International Organization 59, no. 4 (2005): 801-26; Ted Hopf, Social Construction of Foreign Policy: Identities and Foreign Policies, Moscow, 1955 and 1999 (Ithaca, NY: Cornell University Press, 2002); A I Johnston, "Treating, International Institutions as Social Environments," International Studies Quarterly 45, no. 4 (2001): 487-515; Alexander E. Wendt, "Collective Identity Formation and the International State," The American Political Science Review 88, no. 2 (1994): 384-96; Alexander E. Wendt, "Social Theory of International Politics," American Political Science Review 94 (1999): 429.

41. Charles Homans, "Track II Diplomacy: A Short History," Foreign Policy, no. June 20 (2011), http://foreignpolicy.com/2011/06/20/track-ii-diplomacy-a-short-history/.

42. William D. Davidson and Joseph V. Montville, "Foreign Policy According to Freud," Foreign Policy 45 (1982): 153.

43. Mark I. Lichbach, "Thinking and Working in the Midst of Things: Discovery, Explanation, and Evidence in Comparative Politics," in Comparative Politics: Rationality, Culture, and Structure, ed. Mark I. Lichbach and Alan S. Zuckerman (Cambridge: Cambridge University Press, 2009), 18-71; Andrew Bennett and Jeffrey T. Checkel, eds., Process Tracing: From Methaphor to Analytical Tool, International Encyclopedia of Political Science (Cambridge: Cambridge University Press, 2015).

44. As outlined by Checkel Johnston, "Treating, International Institutions as Social Environments," 508-9.

45. “Negotiation as Interactive Problem Solving," International Negotiation 1 (1996): 101.

46. Track Two Diplomacy in the Middle East and South Asia (Santa Monica, CA: RAND Corporation, 2007), 5, http://www.rand.org/pubs/research_briefs/RB9539.html.

47. John Paul Lederach, Preparing for Peace: Conflict Transformation Across Cultures (Syracuse: Syracuse University Press, 1995), 11-24.

48. Johnston, "Treating, International Institutions as Social Environments"; March and Olsen, "The Institutional Dynamics of International Political Orders."

49. See for example Toran Hansen, "Critical Conflict Resolution Theory and Practice," Conflict Resolution Quarterly, 2008, https://doi.org/10.1002/crq.215; Deiniol Lloyd Jones, "Mediation, Conflict Resolution and Critical Theory," Review of International Studies 26, no. 4 (2000): S0260210500006471, https://doi.org/10.1017/S0260210500006471; Jennifer L. Holt and Cynthia James DeVore, "Culture, Gender, Organizational Role, and Styles of Conflict Resolution: A Meta-Analysis," International fournal of Intercultural Relations, 2005, https://oi.org/10.1016/j. ijintrel.2005.06.002; Jeffery S Mullis, "Constructive Conflicts: From Escalation to Resolution," Contemporary Sociology 28, no. 4 (1999): 470-71, https://doi.org/10.2307/2655345.

50. Rolf Tamnes, Oljealder 1965-1995: Norsk utenrikspolitisk historie (Norwegian History of foreign policy) (Oslo: Cappelen Damm, 1997); Iver B Neumann et al., "Norge og alliansene: gamle tradisjoner, nytt spillerom (Norway and the alliances: old traditions, new room for manoeuvre)" (Oslo: Norwegian Institute of International Affairs (NUPI), 2008).

51. Sven G Holtsmark, ed., Naboer i frykt og forventning: Norge og Russland 1917-2014 (Neighbours in Fear and Anticipation: Norway and Russia 1917-2014) (Oslo: Pax Forlag, 2015). 


\section{A. Østhagen}

52. Svalbard is also known as Spitsbergen, which refers to the largest island in the Svalbard Archipelago.

53. Svalbard Treaty, "Treaty between Norway, The United States of America, Denmark, France, Italy, Japan, the Netherlands, Great Britain and Ireland and the British Overseas Dominions and Sweden Concerning Spitsbergen Signed in Paris 9th February 1920." (Longyearbyen: The Governor of Svalbard, 1920), http://www.sysselmannen.no/Documents/Sysselmannen dok/English/Legacy/The_Svalbard_Treaty_9ssFy.pdf.

54. Norwegian Ministry of Justice, "St.meld. Nr. 22 (2008-2009): Svalbard" (Oslo, 2009), $22-23$.

55. Jensen, Norge og havets folkerett (Norway and Law of the Sea), 102.

56. Pedersen and Henriksen, "Svalbard's Maritime Zones: The End of Legal Uncertainty?"

57. Jensen, Norge og havets folkerett (Norway and Law of the Sea), 103.

58. Molenaar, "Fisheries Regulation in the Maritime Zones of Svalbard"; Pedersen, "Endringer i internasjonal Svalbard politikk"; Pedersen, "The Politics of Presence: The Longyearbyen Dilemma."

59. Jensen, Norge og havets folkerett (Norway and Law of the Sea), 110-11.

60. Jensen, 44 .

61. Johan Hammerstrøm, "Russland varsler Svalbard-bråk om nye oljeområder (Russia announces Svalbard-conflict over new oil areas)," E24, 2015, http://e24.no/makro-og-politikk/ russland/russland-varsler-svalbard-braak-om-nye-oljeomraader/23686830.

62. Michael Byers, International Law and the Arctic (New York: Cambridge University Press, 2013), 40; Hønneland, Hvordan skal Putin ta Barentshavet tilbake?, 24-25.

63. Olav Schram Stokke, "Sub-Regional Cooperation and Protection of the Arctic Marine Environment: The Barents Sea," in Protecting the Polar Marine Environment: Law and Policy for Pollution Prevention, ed. DavorVidas (Cambridge: Cambridge University Press, 2000), 124-38.

64. Ole Kristian Bjerkemo, "Interview: Norwegian Efforts for Maritime Traffic Management in the Arctic" (Oslo: September 5, 2016, 2016).

65. Harald Hermansen Eie, "Sjøsikkerhet i det russiske nord," IFS Insight 1/2011 Feb (2011): 1-20.

66. Bjerkemo, "Interview: Norwegian Efforts for Maritime Traffic Management in the Arctic."

67. Thomas Nilsen, "Eyes on the Barents Maritime Safety," Barents Observer, November 24, 2011, http://barentsobserver.com/en/security/eyes-barents-maritime-safety.

68. Norwegian CoastalAuthority, "BarentsSRS-Påbudtskipsrapporteringsystemibarentsomårdet (Barens SRS - Mandatory Vessel Reporting System in the Barents Area),” News, 2013, http:// www.kystverket.no/Nyheter/2013/Mai/pabudt-skipsrapporteringssystem-i-Barentsomradet/.

69. Østhagen, "High North, Low Politics Maritime Cooperation with Russia in the Arctic"; Hønneland, Making Fishery Agreements Work: Post-Agreement Bargaining in the Barents Sea.

70. Hønneland, Hvordan skal Putin ta Barentshavet tilbake?, 38.

71. Norwegian Directorate of Fisheries, "Memorandum om samarbeidsordninger om kontroll mellom det norske Fiskeridirektoratet, den norske Kystvakten, Rosrybolovstvos territorielle administrasjon for Barentshavet og Kvitsiøen og Grensedirektoratet i Russlands føderale sikkerhetstjeneste i Murmansk" (Murmansk, 2013).

72. Geir Hønneland, "Norsk-Russisk miliø- og ressursforvaltning i nordområdene," Nordlit 29 (2012), http://septentrio.uit.no/index.php/nordlit/article/view/2303/2134; Olav Schram Stokke, "International Environmental Governance and Arctic Security," in Geopolitics and Security in the Arctic, ed. Rolf Tamnes and Kristine Offerdal (Abingdon: Routledge, 2014), 121-46; Tore Henriksen and Geir Ulfstein, "Maritime Delimitation in the Arctic: The Barents Sea Treaty," Ocean Development E International Law 42, no. 1-2 (2010): 1-21.

73. Kosmo, "Kystvaktsamarbeidet Norge-Russland. En fortsettelse av politikken med andre midler? (Coast Guard Cooperation Norway-Russia. A Continuation of Politics through Other Means?)." 
74. Rune T Ege, "Norge sier nei til russisk kystvakt-samarbeid (Norway Rejects Russian Coast Guard Cooperation)," VG, July 23, 2012, http://www.vg.no/nyheter/innenriks/forsvaret/ norge-sier-nei-til-russisk-kystvakt-samarbeid/a/10059093/.

75. Andreas Østhagen, “Coastguards in Peril: A Study of Arctic Defence Collaboration,” Defence Studies 15, no. 2 (2015): 7-8.

76. Skram, Alltid til stede: Kystvakten 1997-2017 (Always Present: Coast Guard 1997-2017), 159.

77. Hønneland and Jørgensen, "Kompromisskulturen i Barentshavet (the Culture of Compromise in the Barents Sea)," 61; Arild-Inge Skram, "Interview: Arild-Inge Skram, Former Chief of the Norwegian Coast Guard" (Drammen: October 24, 2017, 2017).

78. Skram, Alltid til stede: Kystvakten 1997-2017 (Always Present: Coast Guard 1997-2017), 163.

79. Norwegian Coast Guard Official I, "Interview: Norwegian Coast Guard Official”; Skram, "Interview: Arild-Inge Skram, Former Chief of the Norwegian Coast Guard."

80. Hønneland and Jørgensen, "Kompromisskulturen i Barentshavet (the Culture of Compromise in the Barents Sea)"; Skram, "Interview: Arild-Inge Skram, Former Chief of the Norwegian Coast Guard"; Norwegian Coast Guard Official II, "Interview: Norwegian Coast Guard Leadership."

81. Skram, Alltid til stede: Kystvakten 1997-2017 (Always Present: Coast Guard 1997-2017), 153-55.

82. Skram, 156-57.

83. Norwegian Coast Guard Official II, "Interview: Norwegian Coast Guard Leadership"; Skram, Alltid Til Stede: Kystvakten 1997-2017 (Always Present: Coast Guard 1997-2017), 159.

84. "When Security Speech Acts Misfire: Russia and the Elektron Incident," 335.

85. Åtland and Bruusgaard, 339.

86. Åtland and Bruusgaard, 341 .

87. Fermann and Inderberg, "Norway and the 2005 Elektron Affair: Conflict of Competencies and Competent Realpolitik," 389, 395.

88. $374,390$.

89. Skram, Alltid til stede: Kystvakten 1997-2017 (Always Present: Coast Guard 1997-2017), 168.

90. 171 .

91. Jarl Eirik Hemner et al., "Arbeidsgruppen for utredning av oppgave- og myndighetsfordelingen mellom Kystvakten, Politiet og Påtalemyndigheten” (Oslo, 2007); Tor Håkon Inderberg, "Norsk Kystvakt - Politi eller Forsvar?," Nordlys, February 19, 2007, https://www.nordlys. no/kronikk/norsk-kystvakt-politi-eller-forsvar/s/1-79-2594494.

92. Skram, "Interview: Arild-Inge Skram, Former Chief of the Norwegian Coast Guard"; Norwegian Coast Guard Official II, "Interview: Norwegian Coast Guard Leadership"; Government Official Norway II, "Interview: Official at Ministry of Defence II."

93. When Norway and Russia claimed their EEZs in 1976 and 1977, a considerable maritime dispute in terms of length arose, as the two countries disagreed on what principle to use when delineating maritime zones. After almost four decades of negotiations with varying intensity, the two countries agreed to a compromise in 2010, splitting the disputed area almost in half. For more, see Arild Moe, Daniel Fjærtoft, and Indra Øverland, "Space and Timing: Why Was the Barents Sea Delimitation Dispute Resolved in 2010?,” Polar Geography 34, no. 3 (2011): 145-62; Michael Byers and Andreas Østhagen, "Why Does Canada Have So Many Unresolved Maritime Boundary Disputes?," Canadian Yearbook of International Law August 11 (2017), https://doi.org/https://doi.org/10.1017/cyl.2017.14.

94. Hønneland, Hvordan skal Putin ta Barentshavet Tilbake?

95. Norwegian Coast Guard Official II, "Interview: Norwegian Coast Guard Leadership."

96. Skram, Alltid til stede: Kystvakten 1997-2017 (Always Present: Coast Guard 1997-2017), 199.

97. Skram, 199-204.

98. Norwegian Coast Guard Official II, “Interview: Norwegian Coast Guard Leadership.” 
99. Skram, Alltid til stede: Kystvakten 1997-2017 (Always Present: Coast Guard 1997-2017), 199-204.

100. Norwegian Coast Guard Official I, "Interview: Norwegian Coast Guard Official"; Norwegian Coast Guard Official II, "Interview: Norwegian Coast Guard Leadership."

101. Andreas Østhagen, "High North, Low Politics Maritime Cooperation with Russia in the Arctic," Arctic Review on Law and Politics 7, no. 1 (2016): 83-100.

102. Aftenposten, "Russisk avis: norsk svalbardpolitikk kan føre til militær konfrontasjon (Russian newspaper: Norwegian Svalbard policy can lead to military confrontation)," October 5, 2017, https://www.aftenposten.no/norge/i/lBxoy/Russisk-avis-Norsk-svalbardpolitikk-kanfore-til-militar-konfrontasjon; Nilsen, "Kommersant: Russia Lists Norway’s Svalbard Policy as Potential Risk of War."

103. KjetilStormark, "Russland trentepåinvasjon av Svalbard(Russiaexercisedinvading Svalbard)," Aldrimer.no, 2017, https://www.aldrimer.no/russland-trente-pa-invasjon-av-svalbard/.

104. Jo Gade and Paal S. Hilde, "Nordområdenes sikkerhetspolitiske betydning for NATO (The importance of the High North for NATO)," in Norge og Russland: sikkerhetspolitiske utfordringer i nordområdene, ed. Tormod Heier and Anders Kjølberg (Oslo: Universitetsforlaget, 2015), 96-110.

105. Marte Lindi et al., "Tilbakeviser at Russiske styrker har øvd på invasjon av Svalbard (Refute that Russian forces practiced invading Svalbard)," NRK, October 18, 2017.

106. Source: data from the Norwegian Coast Guard and Skram, Alltid til stede: Kystvakten 1997-2017 (Always Present: Coast Guard 1997-2017), 151.

107. As described by Åtland and Bruusgaard, "When Security Speech Acts Misfire: Russia and the Elektron Incident"; Hønneland, Russia and the Arctic: Environment, Identity and Foreign Policy, 103-26.

108. Expert Commission, "Unified Effort” (Oslo: Norwegian Ministry of Defence, 2015).

109. Moe, Fjærtoft, and Øverland, "Space and Timing: Why Was the Barents Sea Delimitation Dispute Resolved in 2010?"

110. Hønneland and Jørgensen, "Kompromisskulturen i Barentshavet (the Culture of Compromise in the Barents Sea)."

111. Moe, Fjærtoft, and Øverland, "Space and Timing: Why Was the Barents Sea Delimitation Dispute Resolved in 2010?”

112. Rolf Tamnes and Kristine Offerdal, "Conclusion," in Geopolitics and Security in the Arctic: Regional Dynamics in a Global World, ed. Rolf Tamnes and Kristine Offerdal (Abingdon: Routledge, 2014), 166-77.

114. Oran R. Young, "Institutional Dynamics: Resilience, Vulnerability and Adaptation in Environmental and Resource Regimes," Global Environmental Change 20, no. 3 (2010): 378-85, https://doi.org/10.1016/j.gloenvcha.2009.10.001.

114. Hønneland and Jørgensen, "Kompromisskulturen i Barentshavet (the Culture of Compromise in the Barents Sea)," 66.

115. Hønneland and Jørgensen, 62.

116. Skram, Alltid til stede: Kystvakten 1997-2017 (Always Present: Coast Guard 1997-2017), 204.

117. Norwegian Coast Guard Official II, "Interview: Norwegian Coast Guard Leadership"; Norwegian Coast Guard Official I, "Interview: Norwegian Coast Guard Official.".

118. Skram, "Interview: Arild-Inge Skram, Former Chief of the Norwegian Coast Guard"; Government Official Norway I, "Interview: Official at Ministry of Defence I."

119. Hønneland and Jørgensen, "Kompromisskulturen i Barentshavet (the Culture of Compromise in the Barents Sea)"; Hønneland, Making Fishery Agreements Work: Post-Agreement Bargaining in the Barents Sea; Geir Hønneland, "Co-Management and Communities in the Barents Sea Fisheries," Human Organization 58, no. 4 (1999): 397-404.

120. Checkel, "Constructivism and Foreign Policy." 
121. Government Official Norway I, "Interview: Official at Ministry of Defence I"; Skram, "Interview: Arild-Inge Skram, Former Chief of the Norwegian Coast Guard."

122. Norwegian Coast Guard Official I, "Interview: Norwegian Coast Guard Official"; Norwegian Coast Guard Official II, "Interview: Norwegian Coast Guard Leadership."

123. Joseph V. Montville, "Track Two Diplomacy : The Work of Healing History," The Whitehead Fournal of Diplomacy and International Relations 7, no. 2 (2009): 15-25.

124. Johnston, "Treating, International Institutions as Social Environments"; Checkel, "International Institutions and Socialization in Europe: Introduction and Framework."

125. Author's translation. Norwegian Coast Guard Official II, "Interview: Norwegian Coast Guard Leadership."

126. Author's translation. Original: "Et fellestrekk i disse sakene er at partene møttes akkurat på midten." Hønneland and Jørgensen, "Kompromisskulturen i Barentshavet (the Culture of Compromise in the Barents Sea)," 67.

127. Thomas Risse, ““"Let”s Argue!”: Communicative Action in World Politics," International Organization 54, no. 1 (2000): 1-39.

128. Østhagen, "High North, Low Politics Maritime Cooperation with Russia in the Arctic."

129. "Territory as a Source of Conflict and a Road to Peace," in The SAGE Handbook of Conflict Resolution (London: Sage Publications, 2009), 194.

130. Hønneland, Hvordan Skal Putin Ta Barentshavet Tilbake?

131. Åtland and Bruusgaard, "When Security Speech Acts Misfire: Russia and the Elektron Incident"; Hønneland, Hvordan Skal Putin Ta Barentshavet Tilbake?

132. "When Security Speech Acts Misfire: Russia and the Elektron Incident."

133. See for example R. Emmers, "The Changing Power Distribution in the South China Sea: Implications for Conflict Management and Avoidance," Political Science 62, no. 2 (2010): 118-31; Stephanie Kleine-Ahlbrandt, "Fish Story: The Risk of Conflict in the South China Sea Is Real. But Not for the Reasons You Might Think," Foreign Policy, 2012, http:// foreignpolicy.com/2012/06/25/fish-story/. 